\title{
PERBEDAAN PENURUNAN JUMLAH KOLONI CANDIDA ALBICANS ANTARA PEMBERIAN CEBOKAN REBUSAN BIJI MANJAKANI DAN DAUN SIRIH MERAH PADA WANITA USIA SUBUR (WUS) YANG MENGALAMI KEPUTIHAN
}

\author{
Lia Fitria $^{1}$, M. Nurhalim Shahib ${ }^{2}$, Herri S. Sastramihardja ${ }^{3}$ \\ ${ }^{\mathbf{1}}$ Prodi DIII Kebidanan Fakultas Ilmu Kesehatan Universitas Ibrahimy Situbondo \\ ${ }^{2}$ Departemen Biokimia Fakultas Kedokteran Universitas Padjadjaran \\ ${ }^{3}$ Departemen Farmakologi Fakultas Kedokteran Universitas Padjadjaran \\ Korespondensi: leeafitria@gmail.com
}

\begin{abstract}
Leucorrhoea is one of the most common that occurs in women whose age is returned and occurs $80 \%$ at the age of 15-45 years. One of the herbal plants to overcome leucorrhoea is manjakani seeds (Quercus infectoria Gall) and red betel leaf (Piper crocatum). Manjakani seeds and red betel leaves contain flavonoids, tannins, saponins, triterpenoids, and quinones that contain antibacterial and antifungal properties. This research is a quasi-experimental study with a non-equivalent control group design (pretest and posttest), with a sample involving 28 respondents. The results showed a significant reduction in the number of colonies with $p=0.001(p<0.05)$. The conclusions of this study do not include differences in the number of Candida albicans colonies between administering boiled manjakani seeds and red betel leaves to women of childbearing age (wus) who succeed in recovering vaginal discharge.
\end{abstract}

Keywords: Manjakani Seeds, Red Betel Leaves, Number of Candida albicans colonies, Fertile Women, Leucorrhoea

\begin{abstract}
ABSTRAK
Keputihan merupakan salah satu keluhan yang paling umum terjadi pada wanita usia reproduksi dan terjadi $80 \%$ pada usia 15-45 tahun. Salah satu tanaman herbal untuk mengatasi keputihan adalah biji manjakani (Quercus infectoria Gall) dan daun sirih merah (Piper crocatum). Biji manjakani dan daun sirih merah memiliki kandungan flavonoid, tanin, saponin, triterpenoid dan kuinon yang diyakini sebagai antibakteri dan antijamur. Penelitian ini merupakan studi Kuasi Eksperimen dengan non equivalent (pretest dan posttest) control group design, dengan sampel berjumlah 28 responden. Hasil penelitian perbedaan penurunan jumlah koloni Candida albicans antara pemberian cebokan rebusan biji manjakani dan sirih merah secara statistik tidak bermakna dengan nilai $\mathrm{p}=0,062(\mathrm{p}>0,05)$, dan perbedaan penurunan keluhan keputihan antara pemberian cebokan rebusan biji manjakani dan sirih merah secara statistik bermakna dengan nilai $\mathrm{p}=0,001(\mathrm{p}<0,05)$. Simpulan penelitian ini adalah tidak terdapat perbedaan penurunan jumlah koloni Candida albicans antara pemberian cebokan rebusan biji manjakani dan daun sirih merah pada wanita usia subur (wus) yang mengalami keluhan keputihan.
\end{abstract}

Kata kunci : Biji Manjakani, Daun Sirih Merah, Jumlah koloni Candida albicans, Wanita Usia Subur, Keputihan 


\section{PENDAHULUAN}

Wanita mudah terkena infeksi saluran reproduksi karena struktur anatominya, ditandai dengan adanya gejala keputihan (fluor albus) yang merupakan peristiwa alamiah. (Suryandari, 2015) Setidaknya tiga per empat wanita di dunia pernah mengalami keputihan sekali seumur hidupnya, namun hal ini perlu di waspadai karena dapat berkembang menjadi infeksi akibat adanya bakteri, virus, jamur dan parasit. (Rani, 2015)

Keputihan merupakan salah satu keluhan yang paling umum terjadi pada wanita usia reproduksi dan $80 \%$ terjadi pada usia 15-45 tahun. Wanita dalam kelompok usia reproduksi berisiko mengalami peningkatan terjadinya Candidiasis, trichomoniasis, gonorrhea dan bacterial vaginosis (BV). (Devi, Leela. 2013)

Kandidiasis adalah infeksi yang bersifat akut atau subakut disebabkan oleh jamur candida albicans yang dapat terjadi disekitar vagina. Selain di vagina kandidiasis dapat menyerang di kulit, mukosa oral, bronkus, paru-paru, usus dan organ tubuh yang lainnya. Candida albicans ini merupakan salah satu jenis jamur penyebab keputihan pada vagina wanita, biasanya akan terasa gatal dan keputihan berlebih, berbau tidak sedap sehingga menyebabkan ketidaknyamanan pada bagian genetalia wanita tersebut. (Mayaeari, 2015) Saat ini banyak tanaman herbal yang dimanfaatkan masyarakat sebagai bagian dari pengobatan. Salah satu tanaman herbal tersebut adalah biji manjakani (Quercus infectoria Gall) dan daun sirih merah (Piper Crocatum). Biji manjakani secara empiris di gunakan untuk mengobati berbagai macam penyakit sebagai antiinflamasi, antibakteri dan antijamur. Penggunaan biji manjakani biasa digunakan dalam bentuk sediaan serbuk, kapsul, jamu, pil dan rebusan, namun belum diketahui referensi secara ilmiahnya dalam mengatasi keputihan. Pemeriksaan uji skrining fitokimia yang dilakukan oleh tim peneliti pada studi pendahuluan menunjukkan hasil yang sama dengan penelitian sebelumnya yaitu biji manjakani memiliki kandungan flavonoid, alkoloid, tannin, fenol, saponin, triterpenoid dan kuinon. Mekanisme kerja senyawa flavonoid, tanin, triterpenoid, fenol dan saponin yaitu merusak fungsi membran sel jamur. Tanin terhidrolisis dan fenol 
mempunyai efek sebagai antijamur dengan bereaksi terhadap dinding sel dan menembus membran sel karena dapat merusak protein. Sifat lipofilik flavonoid dapat mengganggu membran jamur. Mekanisme saponin sebagai antijamur yang dapat mengganggu membran jamur dan menghambat pertumbuhannya. Berdasarkan studi pendahuluan yang dilakukan oleh tim peneliti tentang uji aktivitas ekstrak biji manjakani yang dilakukan di laboratorium mikrobiologi Fakultas MIPA ITB didapatkan hasil bahwa kandungan senyawa aktif biji manjakani sebagai antibakteri dan antijamur. Aktivitas KHM (Konsentrasi Hambat Minimum) dan KBM (Konsentrasi Bunuh Minimum) terbesar pada konsentrasi 75.000 ppm dengan zona hambat rata-rata berdiameter $9,8 \mathrm{~mm}$ dan 8,6 mm. Sedangkan KHM dan KBM terendah terdapat pada konsentrasi 12.500 ppm dengan zona hambat $8,2 \mathrm{~mm}$ dan $5,8 \mathrm{~mm}$. Semakin tinggi konsentrasi ekstrak, maka semakin tinggi pula kandungan zat aktif didalamnya sehingga aktivitas antibakteri dan antijamur pada biji manjakani akan semakin besar. Hasil Studi Iminjan, menunjukkan bahwa ekstrak bii manjakani tidak memiliki toksisitas yang signifikan dan uji klinis dapat dilanjutkan dengan aman.

Tanaman sirih merah tumbuh menjalar seperti halnya sirih hijau. Batangnya bulat bertangkai berwarna hijau keunguan dan tidak berbunga. Sirih merah bisa tumbuh dengan baik ditempat yang teduh dan tidak terlalu banyak terkena sinar matahari. Penggunaan daun sirih merah (Piper Crocatum) secara empiris sudah banyak digunakan pada masyarakat sebagai rebusan untuk mengatasi keputihan dan dukungan secara ilmiah dari berbagai referensi penggunaan daun sirih merah ini sudah banyak. (Zubier, 2010) Pada daun sirih merah memiliki kandungan kimia dengan khasiat tertentu yang disebut dengan metabolit sekunder yang menyimpan senyawa aktif seperti flavonoid, senyawa polifenolat, tannin dan minyak atsiri. Senyawa fitokimia yang terkandung dalam daun sirih merah yakni alkaloid, saponin dan flavonoid. Kandungan kimia lainnya yang terdapat di daun sirih merah adalah hidroksikavicol, kavicol, kavibetol, allylprokatekol, karvakrol, eugenol, p-cymene cineole, caryofelen, kadimen estragol, terpenena dan fenil. Karvakrol bersifat desinfektan dan antijamur sehingga bisa digunakan 
untuk mengatasi keputihan. Adapun manfaat lain dari kandungan senyawa pada daun sirih merah yaitu Eugenol yang merupakan turunan dari fenol senyawa minyak atsiri bersifat antijamur dengan menghambat pertumbuhan yeast (sel tunas) dari Candida albicans dengan cara merubah struktur dan menghambat pertumbuhan dinding sel sehingga menyebabkan gangguan fungsi dinding sel dan peningkatan permeabilitas membran terhadap benda asing dan seterusnya menyebabkan kematian sel. (Alves, 2014)

Oleh karena itu, tujuan penelitian ini adalah untuk menganalisis perbedaan penurunan jumlah koloni Candida albicans antara pemberian cebokan rebusan biji manjakani (Quercuss infectoria Gall) dan daun sirih merah (Piper crocatum) pada wanita usia subur (wus) yang mengalami keluhan keputihan.

\section{METODE}

Penelitian ini terdiri dari pembuatan rebusan biji manjakani dan daun sirih merah. Pembuatan rebusan ini dilakukan di rumah peneliti dengan konsultasi terlebih dahulu dengan bagian analis di Laboratorium Farmasi ITB. (Farmakope, 2013)
Subjek dalam penelitian ini adalah wanita usia subur di Puskesmas Sukajadi dan Ledeng kota Bandung yang memenuhi kriteria sampel. Kriteria inklusi: wanita usia subur yang berusia 20-49 tahun, wanita yang sudah/pernah menikah, wanita dengan kandidiasis, wanita yang bersedia menjadi responden dan menandatangani informed consent. Kriteria eksklusi: hamil atau sedang merencanakan kehamilan, sedang menstruasi, sedang menggunakan obat-obatan untuk keputihan, akseptor $\mathrm{Kb}$ hormonal, wanita yang memiliki kulit sensitif atau pernah mengalami reaksi/iritasi setelah menggunakan sabun/produk perawatan didaerah kewanitaan. Wanita usia subur dinyatakan drop out apabila, wanita tidak menggunakan cebokan rebusan manjakani dan daun sirih merah sehari 2X (pagi dan sore), wanita yang mengundurkan diri sebelum penelitian selesai dan pindah alamat.

Penelitian ini merupakan penelitian Kuasi Eksperimen dengan rancangan non equivalent (pretest dan posttest) control group design. Pengambilan sampel dilakukan secara concecutive sampling. (Notoatmodjo, 2010)

Sampel pada penelitian ini sebanyak $\mathrm{n}_{1}=\mathrm{n}_{2}=28$ responden. Kelompok 
perlakuan mendapatkan cebokan penelitian serta berusaha meminimalkan rebusan biji manjakani dan rebusan kerugian yang mungkin timbul dan daun sirih merah selama 7 hari. memaksimalkan penelitian. Penelitian Variabel bebas dalam penelitian ini ini telah mendapatkan ethical clearance adalah pemberian cebokan rebusan biji manjakani dan daun sirih merah, variabel terikatnya adalah jumlah koloni Candida albicans, keluhan keputihan. dari Komite Etik Penelitian Kesehatan Fakultas Kedokteran Universitas Padjadjaran 94 / UN6.C1.3.2 / KEPK / PN / 2017.

Penelitian ini berupaya memegang teguh sikap ilmiah dan etika dalam

\section{HASIL DAN PEMBAHASAN}

Tabel 1. Karakteristik Subjek Penelitian

\begin{tabular}{|c|c|c|c|c|c|}
\hline \multirow{3}{*}{ Karakteristik } & \multicolumn{4}{|c|}{ Perlakuan } & \multirow{3}{*}{ Nilai p } \\
\hline & \multicolumn{2}{|c|}{ Manjakani } & \multicolumn{2}{|c|}{ Sirih Merah } & \\
\hline & $\mathbf{n}$ & $\%$ & $\mathbf{n}$ & $\%$ & \\
\hline Usia & & & & & 0,246 \\
\hline $25-34$ & 10 & 71,4 & 7 & 50 & \\
\hline$>=35$ & 4 & 28,6 & 7 & 50 & \\
\hline Pendidikan & & & & & 0,424 \\
\hline Dasar & 4 & 28,6 & 3 & 21,4 & \\
\hline Menengah & 8 & 57,1 & 6 & 42,9 & \\
\hline Tinggi & 2 & 14,3 & 5 & 35,7 & \\
\hline Pekerjaan & & & & & $\mathbf{0 , 3 8 5}$ \\
\hline Bekerja & 2 & 14,3 & 5 & 35,7 & \\
\hline IRT & 12 & 85,7 & 9 & 64,3 & \\
\hline Jenis kontrasepsi & & & & & 0,693 \\
\hline Tidak ada & 11 & 78,6 & 9 & 64,3 & \\
\hline Kondom & 2 & 14,3 & 3 & 21,4 & \\
\hline Steril & 1 & 7,1 & 2 & 14,3 & \\
\hline IMT & & & & & 0,194 \\
\hline Normal & 8 & 57 & 13 & 93 & \\
\hline Overweight & 6 & 43 & 1 & 7 & \\
\hline
\end{tabular}

Tabel 1. Menunjukkan karakteristik subjek pada kedua kelompok penelitian tidak ada perbedaan yang bermakna ( $p>0,05)$, sehingga layak diperbandingkan. 
Tabel 2. Perbedaan Penurunan Jumlah Koloni Candida albicans antara Pemberian Cebokan rebusan biji manjakani dan daun sirih merah

\begin{tabular}{|c|c|c|c|}
\hline \multirow{2}{*}{$\begin{array}{l}\text { Jumlah koloni } \\
\text { Candida albicans }\end{array}$} & \multicolumn{2}{|c|}{ Perlakuan } & \multirow[t]{2}{*}{ Nilai p* } \\
\hline & $\begin{array}{c}\text { Manjakani } \\
(\mathbf{n}=\mathbf{3 0})\end{array}$ & $\begin{array}{c}\text { Sirih merah } \\
(\mathrm{n}=\mathbf{3 0})\end{array}$ & \\
\hline $\begin{array}{l}\text { Pre } \\
\text { Rerata (SD) } \\
\text { Median } \\
\text { Rentang }\end{array}$ & $\begin{array}{c}2,985 \times 10^{3}\left(2,784 \times 10^{3}\right) \\
1,900 \times 10^{3} \\
30-8820\end{array}$ & $\begin{array}{c}3,775 \times 10^{3}\left(2610 \times 10^{3}\right) \\
3,475 \times 10^{3} \\
150-9880\end{array}$ & 0,329 \\
\hline $\begin{array}{l}\text { Post } \\
\text { Rerata (SD) } \\
\text { Median } \\
\text { Rentang }\end{array}$ & $\begin{array}{c}6,67 \times 10^{2}\left(806 \times 10^{2}\right) \\
5,03 \times 10^{2} \\
10-3200\end{array}$ & $\begin{array}{c}5,88 \times 10^{2}\left(927 \times 10^{2}\right) \\
2,04 \times 10^{2} \\
10-31000\end{array}$ & 0,285 \\
\hline $\begin{array}{l}\text { Perbedaan pre dan } \\
\text { post }\end{array}$ & $\mathrm{p}=0,001$ & $\mathrm{p}=0,001$ & \\
\hline $\begin{array}{l}\text { \% Penurunan } \\
\text { jumlah koloni } \\
\text { Candida albicans } \\
\text { (Median) }\end{array}$ & 71 & 92 & 0,062 \\
\hline
\end{tabular}

Tabel 2. menunjukkan tidak ada perbedaan penurunan jumlah koloni Candida albicans antara pemberian cebokan rebusan biji manjakani dan daun sirih merah karena secara statistik tidak bermakna dengan nilai $\mathrm{p}=0,062(\mathrm{p}>0,05)$.

Tabel 3. Perbedaan Penurunan Keluhan Keputihan Antara Pemberian Cebokan Rebusan Biji Manjakani dan Daun Sirih Merah Pada Wanita Usia Subur (WUS)

\begin{tabular}{|c|c|c|c|}
\hline \multirow[b]{2}{*}{$\begin{array}{c}\text { Jumlah koloni } \\
\text { Candida albicans }\end{array}$} & \multicolumn{2}{|c|}{ Perlakuan } & \multirow[t]{2}{*}{ Nilai $p^{*}$} \\
\hline & $\begin{array}{c}\text { Manjakani } \\
(\mathbf{n}=30)\end{array}$ & $\begin{array}{c}\text { Sirih merah } \\
(\mathbf{n}=\mathbf{3 0})\end{array}$ & \\
\hline Pre & & & 0,164 \\
\hline Rerata (SD) & $5(1)$ & $4(1)$ & \\
\hline Median & 5 & 4 & \\
\hline Rentang & $3-7$ & $3-7$ & \\
\hline Post & & & 0,114 \\
\hline Rerata (SD) & $1(0)$ & $1(0)$ & \\
\hline Median & 1 & 1 & \\
\hline Rentang & $1-2$ & $1-2$ & \\
\hline $\begin{array}{l}\text { Perbedaan pre dan } \\
\text { post }\end{array}$ & $p=0,001$ & $p=0,001$ & \\
\hline $\begin{array}{l}\text { \% Penurunan } \\
\text { Keluhan keputihan } \\
\text { (Median) }\end{array}$ & 80 & 66,7 & 0,001 \\
\hline
\end{tabular}


Tabel 3. menunjukkan terdapat perbedaan penurunan keluhan keputihan sebelum dan sesudah pemberian cebokan rebusan biji manjakani dan daun sirih merah secara statistik terdapat perbedaan yang bermakna dengan nilai $\mathrm{p}=0,001 \quad(\mathrm{p}<0,05)$. Prosentase penurunan median keluhan keputihan pada kelompok perlakuan daun manjakani lebih tinggi daripada kelompok Sirih merah (80\% vs 66,7\%) secara statistik perbedaan ini bermakna dengan nilai $\mathrm{p}=0,001(\mathrm{p}<0,05)$.

\section{Perbedaan Penurunan Jumlah Koloni Candida albicans Antara Pemberian Cebokan Rebusan Biji Manjakani dan Daun sirih Merah Pada Wanita Usia Subur (WUS) Yang Mengalami Keluhan Keputihan.}

Dari hasil penelitian seperti ditunjukkan pada tabel 2 tidak terdapat perbedaan penurunan jumlah koloni Candida albicans antara pemberian cebokan rebusan biji manjakani dan daun sirih merah karena secara statistik tidak bermakna dengan nilai $\mathrm{p}=0,062(\mathrm{p}>0,05)$.

Pada masa ovulasi yaitu masa subur ketika sel telur siap dibuahi, leher rahim dibagian atas vagina memproduksi lebih banyak cairan. Keputihan dapat disebabkan infeksi bakteri seperti gonococus, chlamydia, trichomatis, infeksi jamur seperti Candida dan infeksi parasit seperti trichomonas vaginalis, serta adanya infeksi virus seperti candylomata acuminata dan herpes. Keputihan juga dapat terjadi karena kurang terjaganya kebersihan diri sehingga timbul jamur atau parasit. (Devi, 2013)

Upaya yang dapat dilakukan untuk mengatasi keputihan yaitu dengan menjaga kebersihan sekitar area kewanitaan dan menggunakan perawatan secara herbal. Salah satu tumbuhan yang berkhasiat sebagai obat untuk keputihan adalah biji manjakani dan daun sirih merah yang telah banyak digunakan oleh masyarakat.

Manjakani menghasilkan gal yang muncul pada ranting muda atau daun sebagai reaksi akibat tusukan serangga Cynips gallae tinctoria. Gal manjakani menunjukkan efek anti inflamasi, anti bakteri dan anti jamur karena sebagian besar mengandung tanin (50-70\%) dan sebagian kecil mengandung asam galat dan asam elagat. (Yanti, 2016)

Pada rebusan biji manjakani terdapat senyawa fitokimia yang dapat menurunkan jumlah koloni Candida albicans yaitu berpotensi efektif untuk mengobati peningkatan kasus 
kandidiasis lokal dan sistemik karena memiliki spektrum yang luas sebagai aktivitas anti-mikroba. Senyawa yang dapat merusak komponen dinding sel jamur diantaranya senyawa tanin dan fenol, tanin terhidrolisis dan fenol mempunyai efek sebagai antijamur dengan bereaksi terhadap dinding sel dan menembus membran sel karena dapat merusak protein. Sifat lipofilik flavonoid dapat mengganggu membran jamur. Mekanisme saponin sebagai antijamur yang dapat mengganggu membran jamur dan menghambat pertumbuhannya. (Shrestha, 2014)

Aktifitas ekstrak biji manjakani terhadap beberapa jamur seperti Candida albicans dan glabalata menunjukkan adanya kemampuan antifungal untuk menghambat pertumbuhan dan perkembangan yeast (sel tunas) dari Candida albicans dengan cara menghancurkan kerja organel-organel sel jamur, menganggu biosintesis dinding sel dan membran, sistem metabolisme, sistem enzim, perubahan permeabilitas dinding sel menjadi lebih tinggi menyebabkan penurunan volume sel, dan membuat sel mengerut hingga mengalami lisis. (Yanti, 2016)
Perawatan herbal untuk mengatasi keputihan selain penggunaan biji manjakani adalah daun sirih merah (Piper crocatum). Daun sirih merah merupakan salah satu jenis dari tanaman merambat dengan bentuk daun seperti hati berwarna merah dan biasanya hidup pada daerah dataran tinggi. Penggunaan secara tradisional biasanya dengan merebus daun sirih merah kemudian air rebusan digunakan untuk kumur atau membersihkan bagian tubuh lainnya termasuk dicebokkan. Tidak terdapat perbedaan antara biji manjakani dan daun sirih merah karena kandungan kimia yang terdapat pada daun sirih merah juga dimiliki biji manjakani dalam menghambat pertumbuhan jumlah koloni Candida albicans akan tetapi cara kerja pada masing-masing senyawa kimia berbeda. Kandungan kimia tanaman sirih merah belum diteliti secara detail. Daun sirih merah mengandung Alkoloid, flavonoid, senyawa polifenolat, tanin, dan minyak atsiri. Senyawa fitokimia yang terkandung dalam daun sirih merah yakni alkaloid, saponin dan flavonoid. Kandungan kimia lainnya yang terdapat didaun sirih merah adalah hidroksikavicol, kavicol, kavibetol, allylprokatekol, karvakrol, eugenol, p- 
cymene, cineole, caryofelen, kedimen estragol, terpenena dan fenil propada. Alkaloid bersifat detoksifikan yang dapat menetralisir racun. Flavonoid dan polivenolat bersifat antioksidan, antidiabetik, antikanker, antiseptik, dan antiinflamasi. Tanin memiliki kemampuan dalam mengikat dan mengendapkan protein serta sebagai antibakteri sedangkan minyak atsiri yang mengandung diantaranya chavikol dan chavibetol yaitu senyawa yang mempunyai khasiat antiseptik, serta eugenol dalam daun sirih merah yang bersifat sebagai antifungi dalam menghambat pertumbuhan yeast (sel tunas) dari Candida albicans dengan cara merubah struktur dan menghambat pertumbuhan dinding sel sehingga menyebabkan gangguan fungsi dinding sel dan peningkatan permeabilitas membran terhadap benda asing dan menyebabkan kematian sel. (Jawetz, 2010)

Perbedaan Penurunan Keluhan Keputihan antara Pemberian Cebokan Rebusan Biji Manjakani dan Daun Sirih Merah pada Wanita Usia Subur (WUS).

Dari hasil penelitian tabel 3 menunjukkan terdapat perbedaan penurunan keluhan keputihan sebelum dan sesudah pemberian cebokan rebusan biji manjakani dan daun sirih merah secara statistik terdapat perbedaan yang bermakna dengan nilai $\mathrm{p}=0,001 \quad(\mathrm{p}<0,05) . \quad$ Prosentase penurunan median keluhan keputihan pada kelompok perlakuan daun manjakani lebih tinggi daripada kelompok Sirih merah (80\% vs $66,7 \%$ ) secara statistik perbedaan ini bermakna dengan nilai $\mathrm{p}=0,001 \quad(\mathrm{p}<0,05)$. Perbandingan ini terbalik dengan penurunan jumlah koloni Candida albicans yang lebih tinggi pada pemberian cebokan rebusan daun sirih merah dibandingkan dengan cebokan rebusan daun sirih merah karena ada beberapa hal diantaranya pengumpulan data pada pemeriksaan keluhan dilakukan secara subjektif dan tidak dapat dikontrol serta bersifat bias.

Keputihan merupakan salah satu keluhan yang paling umum terjadi pada wanita usia reproduksi dan terjadi $80 \%$ pada usia 15-45 tahun. Wanita dalam kelompok usia reproduksi berada pada peningkatan risiko untuk bisa terjadinya candidiasis, trichomoniasis, gonorrhea dan bacterial vaginosis (BV). Hasil penelitian menyebutkan kejadian infeksi yang disebabkan keputihan adalah $24 \%$ candidiasis, $20 \%$ bacterial vaginosis, $8 \%$ trichomoniasis dan $48 \%$ tidak di temukan kasus penyebab infeksi 
keputihan dan dapat di kategorikan keputihan fisiologis. Secara umum, keputihan bisa disebabkan oleh beberapa faktor yaitu, kurangnya perhatian terhadap kebersihan organ kewanitaan, kelembaban yang tinggi didaerah organ kewanitaan, membasuh organ kewanitaan kearah yang salah, aktivitas fisik yang sangat melelahkan, stress, pola hidup yang kurang sehat, menggunakan sabun secara berlebihan dan sering menggunakan pakaian dalam yang ketat dan lembab.

Upaya pencegahan dan pengobatan guna untuk mengurangi permasalahan keputihan dapat digunakan pengobatan secara herbal yang berasal dari tumbuhan dan bahan bahan alami murni yang tidak memiliki efek samping, tingkat bahaya dan resiko yang jauh lebih rendah dibandingkan dengan obat kimia sintetis. Salah satu tanaman potensial yang terdapat di Indonesia yang sudah dimanfaatkan untuk pengobatan keputihan diantaranya biji manjakani (Quercuss infectoria Gall) dan daun sirih merah (Piper crocatum).

Pada biji manjakani terdapat kandungan kimia yang memiliki kemampuan antifungal untuk menghambat pertumbuhan dan perkembangan yeast (sel tunas) dari Candida albicans sehingga dapat mengatasi keluhan keputihan yang dirasakan oleh wanita khususnya wanita usia subur.

Pada daun sirih merah juga dapat menurunkan keluhan keputihan dikarenakan daun sirih merah merupakan bahan alami, sangat mudah didapat dan penggunaannya tidak membutuhkan biaya tinggi seperti antibiotik. Penelitian Zubier mengenai efikasi sabun ekstrak sirih merah dalam mengurangi gejala keputihan juga menunjukkan bahwa penggunaan sabun ekstrak sirih merah yang digunakan 2 kali sehari selama 1 minggu efektif dalam mengurangi lendir pada keputihan fisiologis, tanpa mengganggu flora normal. Hasil pengurangan lendir ini konsisten didapatkan baik dari penilaian peneliti maupun subjek penelitian.

\section{SIMPULAN}

1. Tidak terdapat perbedaan penurunan jumlah koloni Candida albicans antara pemberian cebokan rebusan biji manjakani (Quercus infectoria Gall) dan daun sirih merah (Piper crocatum) pada wanita usia subur 
(WUS) yang mengalami keluhan keputihan.

2. Terdapat perbedaan penurunan keluhan keputihan antara pemberian cebokan rebusan biji manjakani (Quercus infectoria Gall) dan daun sirih merah (Piper crocatum) pada wanita usia subur (WUS).

\section{DAFTAR PUSTAKA}

Suryandari FD, Rufaida Z. Hubungan pemakaian sabun pembersih kewanitaan dengan terjadinya keputihan pada wanita usia subur (WUS) di Desa Karang Jeruk Kecamatan Jatirejo Kabupaten Mojokerto. Hospital Majapahit. 2013;5(1).

Rani UY, Sarada D, Varalakshmi D, Rajeswari RM, Padmaja Y. Microbiological study of leucorrhoea with special reference with special reference to gardnerella vaginalis. Int $\mathbf{J}$ of Advanced Research. 2015(3)7:1192-1199.

Devi US. A study on prevalence of leucorrhoea in women attending in OPD of gynecology and obstetrics departement in a tertiary hospital. Int $\mathbf{J}$ of Research in Health Sciences. Oct-Dec 2013;1(3):230-34.
Leela PK, Ramana VK, Mandhuri LV. Evaluation of various causes of leucorrhoea in sexually active females. Int $\mathbf{J}$ of Current Pharma \& Clin Research. 2013;2(3):93-6.

Mayasari IC, Khuzaiyah S, Krisiyanti R. Karakteristik wanita dengan flour albus. Jurnal ilmu kesehatan (JIK). 2015;7(1).

Shafaie SF, Namazi A. Prevalence, risk factors, and clinical findings of candidiasis and trichomoniasis in women supported by selected health centers of tabriz, Iran. Crescent $\mathbf{J}$ of Medical and Bio Scien. 2014;3(4):130.

Yanti N, Samingan, Mudatsir. Uji aktivitas antifungi ekstrak etanol gall manjakani (Quercus infectoria Gall) terhadap Candida albicans. Jurnal Ilmiah Mahasiswa Pendidikan Biologi. 2016(1)1:1-9.

Nurcahyo H. Pengaruh minyak atsiri daun sirih merah (Piper crocatum Ruiz \& Pav) terhadap pertumbuhan jamur Candida albicans. 2010.

Shrestha S, Kaushik SV, Eshwarappa BSR, Subaramaihha RS, Ramanna ML, Lakkappa BD. Pharmacognostic studies of insect gall of Quercus infectoria olivier (Fagaceae). Elsevier. 2014;4(1):35-9. 
Leela T. Studies on the antibacterial activity of quercus infectoria galls. Int Conference on Bioscience, Biochemistry and Bioinformatics. 2011(5):410.

Iminjan M, Amat N, Li HX, Upur H, Ahmat D, He Bin. Investigation into the toxicity of traditional uygur medicine quercus infectoria galls water extract. Plos One. March 2014;9(3):e90756.

Pin KY, Chuah GT, Rashih AA, Rasadah AM, Choong YST, Law LC. Effects of the concentration of Quercus infectoria galls (manjakani) extraxt on moisture content and quality of its freeze-dried product. Int $\mathrm{J}$ of Engineering and Tecno. 2006;3(2):167-74.

Jawetz E, Melnick, Adelberg. Medical microbiology. 25thEd. Mc Graw Hill. 2010:625-661.

Zubier F, Bramono K, Widaty S, Nilasari H, Louisa M, Rosana Y. Efikasi sabun ekstrak sirih merah dalam mengurangi gejala keputihan fisiologis. Maj Kedok Indon. 2010;60(1):9-14.

Gunawan S. Mekanisme daya hambat kombinasi ekstrak daun sirih hijau (Piper betle linn) dan ekstrak daun sirih merah (Piper crocatum) terhadap pertumbuhan candida albicans (Eksperimental laboratoris).2010[SKRIPSI].

Alves TC, Silva S, Pereira L, Williams WD, Azeredo J, et.al. Effect of progesterone on Candida albicans vaginal pathogenicity. Int $\mathbf{J}$ of Med Microbiol. 2014:1011-17.

Suplemen III. Farmakope Herbal Indonesia. Edisi I ed. Jakarta: Kemenkes RI, 2013.

Notoatmodjo. Metodologi Penelitian Kesehatan. Jakarta: Rineka Cipta, 2010.

Satari MH, Wirakusumah FF. Konsistensi Penelitian dalam Bidang Kesehatan. Bandung: Refika Aditama, 2011.

BPOM RI. Acuan sediaan herbal. 2011(6):Ed 1 